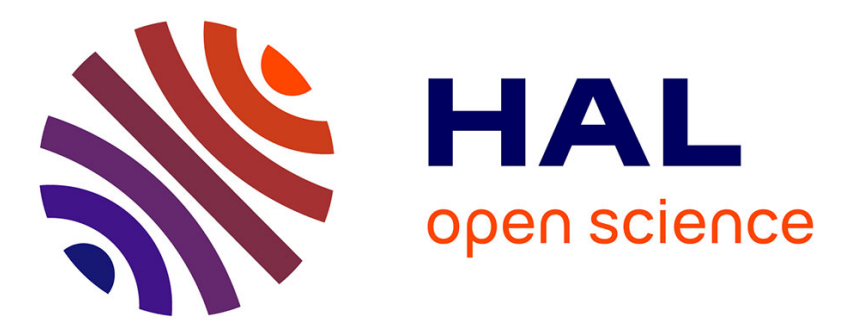

\title{
Closing the loop on platinum from catalytic converters: Contributions from material flow analysis and circularity indicators
}

Michael Saidani, Alissa Kendall, Bernard Yannou, Yann Leroy, François Cluzel

\section{- To cite this version:}

Michael Saidani, Alissa Kendall, Bernard Yannou, Yann Leroy, François Cluzel. Closing the loop on platinum from catalytic converters: Contributions from material flow analysis and circularity indicators. Journal of Industrial Ecology, 2019, 10.1111/jiec.12852 . hal-02094798

\section{HAL Id: hal-02094798 \\ https://hal.science/hal-02094798}

Submitted on 10 Apr 2019

HAL is a multi-disciplinary open access archive for the deposit and dissemination of scientific research documents, whether they are published or not. The documents may come from teaching and research institutions in France or abroad, or from public or private research centers.
L'archive ouverte pluridisciplinaire HAL, est destinée au dépôt et à la diffusion de documents scientifiques de niveau recherche, publiés ou non, émanant des établissements d'enseignement et de recherche français ou étrangers, des laboratoires publics ou privés. 


\title{
CLOSING THE LOOP ON PLATINUM FROM CATALYTIC CONVERTERS: CONTRIBUTIONS FROM MATERIAL FLOW ANALYSIS AND CIRCULARITY INDICATORS
}

\author{
Michael Saidani ${ }^{1}$, Alissa Kendall ${ }^{2}$, Bernard Yannou ${ }^{1}$, Yann Leroy ${ }^{1}$, François Cluzel ${ }^{1}$ \\ ${ }^{1}$ Laboratoire Genie Industriel, CentraleSupélec, Université Paris-Saclay, France \\ ${ }^{2}$ Department of Civil and Environmental Engineering, University of California-Davis, U.S.
}

Contact author: michael.saidani@centralesupelec.fr

\begin{abstract}
In this study, material flow analysis (MFA) is applied to quantify and break the obstacles for advancing a circular economy (CE) of platinum ( $\mathrm{Pt}$ ) from catalytic converters $(\mathrm{CC})$ in Europe. First, the value chain and related stakeholders are mapped out in a MFA-like model to both facilitate the assessment of stocks and flows, and get a comprehensive view of potential action levers and resources to close-the-loop. Then, through the cross analysis of numerous data sources, two MFA are completed: (i) one general MFA, and (ii) one sector-specific MFA, drawing a distinction between the fate of Pt from (a) light-duty vehicles, under the ELV Directive 2000/EC/53, and (b) heavy-duty and off-road vehicles. Key findings reveal a leakage of around 15 tons of Pt outside the European market in 2017. Although approximately one quarter of the losses are due to in-use dissipation, $65 \%$ are attributed to insufficient collections and unregulated exports. Comparing the environmental impact between primary and secondary production, it has been estimated that halving the leakages of Pt during usage and collection could prevent the energetic consumption of $1.3 \times 10^{3} \mathrm{TJ}$ and the greenhouse gases emission of $2.5 \times 10^{2} \mathrm{kt} \mathrm{CO} 2 \mathrm{eq}$. Through the lens of circularity indicators, activating appropriate action levers to enhance the CE performance of $\mathrm{Pt}$ in Europe is of the utmost importance in order to secure future productions of new generations of $\mathrm{CC}$ and fuel cells. Moreover, the growing stockpile of Pt from CC in use urges for better collection mechanisms. Also, the CC attrition during use and associated Pt emissions in the environment appears as non-negligible. Based on the scarce and dated publications in this regard, we encourage further research for a sound understanding of this phenomenon that can negatively impact human health.
\end{abstract}

\section{KEYWORDS}

Circular economy, platinum, catalytic converter, value chain, MFA, circularity indicators.

\section{ACRONYMS}

CC: Catalytic converters

CE: Circular economy

CRM: Critical raw materials

EC: European Commission

EU: European Union

MFA: Material flow analysis

PGM: Platinum group metals

Pt: Platinum 


\section{INTRODUCTION}

\subsection{Context and motivations}

\subsubsection{Foreword}

Critical raw materials (CRM) are one of the five priority sectors identified in the European Union (EU) action plan (EC, 2015) for a more circular economy (CE). Platinum (Pt) is one of the $27 \mathrm{CRM}$ listed by the European Commission, based on its high economic importance, supply risk, import reliance, and low end-of-life recycling input rate (EC, 2017). The key objectives of the European policy (EC, 2015) on CRM are: (i) the reduction of import dependency by improving supply conditions from EU and other sources and providing resource efficiency and alternatives in supply; (ii) bringing Europe to the forefront in raw materials sectors and mitigating their negative environmental and social impacts. Actually, platinum group metals (PGM) are fundamental for emerging technologies - e.g. the platinum currently in use in catalytic converters (CC) and soon in fuel cells (Valérian, 2016; Senk et al. 2012) - and the EU is $98 \%$ reliant on platinum imports (EC, 2017). In Europe, the demand of platinum is mainly driven by their use in CC (notably for diesel applications) - 69\% of the overall demand, estimated approximately to 70 tonnes (Deloitte Sustainability, 2017) - which are mandatory devices used to reduce tailpipe emissions from motorized vehicles. Note that the major consumption of platinum is indeed in diesel-powered vehicles (including light-duty, heavyduty and off-road vehicles) as it is particularly effective under oxygen-excessive conditions (Golunski, 2007). For petrol-powered vehicles platinum and palladium can be equally effective, and so the choice is often made on the basis of their relative cost.

The European Commission (2014) defines the CE as an economy "where the value of products, materials and resources is maintained in the economy for as long as possible, and the generation of waste minimised". On this basis, securing a sustainable availability of CRM can be accomplished by improving the circularity efficiency of the entire value chain e.g. through the implementation of closed-loop approaches (Stahel, 2016). In fact, the adoption of CE strategies can be a long-term strategy to mitigate the risks of CRM supply at the European scale (Gaustad et al. 2018; UNEP, 2013) e.g. by improving recycling rates of scarce metals from end-of-life vehicles (Andersson et al. 2017) like the platinum which may be functionally recycled in its main application without facing the issue of downcycling. Furthermore, state-of-the-art refining centers can recover up to $98 \%$ of the platinum from used CC (JM, 2017). As such, platinum appears as an ideal candidate for the application of CE principles. Yet, currently the circularity performance of platinum in Europe is not optimal: the recycling rate of platinum from CC is estimated to be between 50 and $60 \%$ (Hagelüken et al. 2016), indicating thus opportunities for improvement in a context of CE of products and materials.

Complementary to prior academic and industrial works discussing ways to close-the-loop on platinum, the main objective of this study consists of clarifying the current European value chain of platinum from CC in an operational way, that is to say, to map both qualitatively and quantitatively the distribution of flows, stocks and losses, as well as the stakeholders on this value chain, using material flow analysis (MFA). As a result, key economic, environmental and organizational value buckets are highlighted. The findings provide a relevant basis to support industrial actors, decisionmakers, and policy-makers, in the orientation of their actions, in the way they will be in a better position to visualize where to act, which stakeholders are involved, and what level of improvement - e.g. environmental and economic benefits - could be expected. The main contribution of this paper is thus in accordance with Senk et al. (2012) and Andersson et al. (2017), sharing that the increase of deep knowledge on the use and end-of-life pathways of CRM in the EU will enable the European society to transfer more resources into economically efficient and technically manageable metal reserves.

\subsubsection{Understanding the supply risk for the EU}

The European Commission (EC, 2017) highlights the economic importance of platinum and its associated supply risk for the EU. The following elements, extracted from various sources and summarized hereafter, provide a better and comprehensive understanding of these concerns for the EU:

- Concentrated production: First, the fact that European mining projects cannot compete 
worldwide production makes it essential to develop better recycling processes, so as to strengthen the autonomy and competitive edge of the European industry (CGE, 2015; Alonso et al. 2012). In fact, the EU mine production makes a small contribution to the European platinum supply, with an annual production of about one tonne (EC, 2017) when the overall European annual demand is around 70 tonnes. The EU is actually dependent on imports for the majority of metals that feed technology and advanced industries, such as platinum coming mainly from South Africa and Russia, where longterm stability is not assured (Cetim, 2017). For instant, in 2012, strikes by South African miners have impacted on production and may do so in the future (Sievers and Tercero, 2012).

- Declining ore grades: The average PGM concentration in the mines - e.g. in South Africa - is below $10 \mathrm{~g} / \mathrm{t}$ (Hagelüken, 2014) and usually between 2 and 6 grams per ton (IPA, 2016). In addition, the PGM industry is progressively forced to exploit lower grades and more expensive PGM ores (Bardi and Carporali, 2014), resulting in increasingly higher cost, as well as $\mathrm{CO}_{2}$ emissions and energy consumption for the production of primary platinum. On the opposite, catalytic converter contains some 2,000 g/t of PGM in the ceramic brick (Hagelüken, 2014) making their recovery attractive from a sustainability standpoint. In a nutshell: platinum primary mining is characterized by low grade, high volume and fixed location; platinum urban mining is characterized by high grade, millions of units and global dissemination. In this context, extracting urban mines seems therefore a suitable sustainable solution to avoid landfill of metals and overcome long-term supply disruptions. Yet, without proper collection mechanisms of such CC and sufficient end-of-life infrastructures, the platinum contained in CC can remain an orebody without a mineable volume in the EU.

- Increasing demand: It is acknowledged that the demand of PGM will increase in the years ahead (JM, 2016; EC, 2015; Alonso et al. 2012) due to: (i) the imposition of increasingly strict emission control e.g. in the heavy-duty and off-road sector, which has been and will continue to be a source of significant platinum demand growth in response to the introduction of the Euro VI legislation for heavy-duty vehicles in 2014 and the preparation of the Stage V legislation for non-road engines becoming active in 2020; (ii) the expected increase of fuel cells in electric vehicles (Nel, 2004). Indeed, according to Johnson Matthey (2016): "In the longer term the move away from carbon-based fuels for powering road vehicles may lead to reduced demand for platinum in catalytic converters. However, if fuel cell vehicles achieve significant market penetration in the future this is very likely to lead to increased demand for platinum".

\subsubsection{Environmental and economic challenges}

Out of 63 metals investigated and compared on a per kilogram basis, Nuss and Eckelman (2014) revealed that the platinum group metals and gold display the highest environmental burdens. The environmental impact of the primary production of platinum is actually tremendous: around 40 tons $\mathrm{CO}_{2}$ eq. plus $200 \mathrm{GJ}$ to produce 1 kilogram of platinum (see section 4.3). Hopefully, the secondary production of PGM can significantly minimize the environmental impact - i.e. regarding emission reduction and energy savings - of the overall PGM supply, especially when state-of-the-art technologies from European refining centers are used (Van der Voet, 2018; Hagelüken et al. 2016). In fact, it has been estimated in average that the use of secondary platinum from end-of-life CC could divide by 20 the environmental cost (see section 4.3). In addition to this environmental value bucket, the high value of PGM makes their recycling attractive (Mathieux et al. 2017): the price of 1 kilogram of platinum has indeed fluctuated around an average of $30,000 €$ over the last decade. As a consequence, there is an important interest for European industrialists to recover the remaining material quantity of their systems, notably for European actors who need to buy platinum to manufacture catalytic converters. Moreover, the reuse of PGM metals recovered from catalytic converters does not require high costs compare to primary ore extraction (Fornalczyk and Saternus, 2013), notably at a time mining conditions are expected to become increasingly difficult due to lower ore grades. On this basis, closing-the-loop of PGM in Europe is of the utmost importance both from economic and ecological viewpoints (Fornalczyk and Saternus, 2013). Despite all that, the recycling rate of platinum from automotive catalysts is only estimated to 50-60\% (Hagelüken et al. 2016; UNEP, 2013). To cite the UNEP (2013): "Taking the relative price levels of precious metals into account, it seems surprising that those metals do not have the highest end-of-life recycling rates among all 
metals". This reality is even more regrettable when one knows $98 \%$ of the PGM content of spent automotive catalysts can be repeatedly recovered (JM, 2017) using state-of-the-art recycling centers. All in all, it seems not only feasible but also of great importance to enhance the circularity performance of platinum contained in catalytic converters.

\subsection{Research gaps and contributions}

In the past, several authors have proposed and discussed possible measures for improving the recycling rates of CRM and thus their circularity performance. For instance, Gaustad et al. (2018) examined CE strategies to mitigate critical material supply issues. Accordingly, Lapko et al. (2018) made a focus on closed-loop supply chain (CLSC) as a promising strategy for securing long-term availability of materials. Their findings underline the need for interactions between supply chain actors, a sound competitive environment for recycling processes, and investment in technologies and infrastructure development if CLSC for CRM is to be developed. More precisely, the work of Hagelüken and colleagues $(2009,2012,2014$, and 2016, just to name a few) provide the most advanced research on the issue of recovery platinum from autocatalysts both at the German and European scales, including extensive discussions on relevant potential action levers to close-theloop. To close the recycling loop new business models will need to be introduced to provide strong incentives for returning products at their end-of-life (EoL), efficient collection being the largest challenge to Hagelüken (2014). The gap to reach an augmented recycling rate is also caused among other factors by exports of EoL vehicles to regions with insufficient recycling infrastructures, and by a long and opaque EoL value chain in Europe (Hagelüken et al. 2016).

In fact, the entire value chain of platinum in the EU is complex and difficult to quantify accurately regarding the large number of actors involved and the distribution of vehicles all across Europe, including imports and exports. Despite these difficulties, its modeling appears to be a prerequisite in the gain of deep - quantitative and localized - knowledge, with the aim to advance a CE of platinum in Europe. In previous work, Saurat and Bringezu (2008) analyze three platinum group metals (platinum, palladium, rhodium) and the environmental impacts associated with their supply in Europe through MFA, in combination with a model of environmental pressures related to the production of PGM outside Europe. This study provides results for the year 2004 within the geographical scope of the EU-25, plus Norway and Switzerland, taking into consideration the major industrial sectors of PGM use, namely the chemical, petroleum, and glass industries; jewelry, dentistry, electronic equipments; and car catalysts. More recently, following the call for a "study on data needs for a full raw materials flow analysis" launched by the European Commission in 2012, a materials system analysis (MSA) was carried out to investigate the flows and stocks of 28 raw materials throughout their entire life cycle, including the platinum (BIO by Deloitte, 2015). MSA is similar to a MFA in the way it consists of a mapping of the flows of materials through the economy, as raw materials, components or products, in terms of entry into the economy (extraction and import), movement through the economy (production, consumption, and exports), additions to stock, and end-of-life through either disposal or recovery. This study provides results for the year 2012 within the geographical scope of the EU-28, considering as well as the main product groups using platinum (i.e. catalysts, electronic, jewellery, and biomedical applications).

A first contribution of this article is to update the previous MFA related to the platinum value chain in the EU which provide results for the year 2004 (Saurat and Bringezu, 2008) and 2012 (BIO by Deloitte, 2015). A comparison between these previous studies and the present findings - e.g. the evolution and order of magnitude of the flows, their environmental repercussions - is notably discussed in section 4 . Interestingly, the present study has the following distinguishing characteristics and contributions:

- Specific focus on the platinum from catalytic converters within the EU, and modeling the associated value chain system at a detailed level: this study is indeed sector-and product-specific, and complement therefore more general studies dealing with the overall European platinum value chain (BIO by Deloitte, 2015; Saurat and Bringezu, 2008).

- Demarcation between platinum contained in light vehicles, under the ELV Directive $2000 / E C / 53$ and platinum contained in heavy vehicles, not subject to mandatory minimum recycling or recovery rates.

- Mapping of key actors on the value chain, i.e. of actors who can have an influence on the circularity performance of platinum in the EU. 
To cite this version: Saidani, M, Kendall, A, Yannou, B, Leroy, Y, Cluzel, F. Closing the loop on platinum from catalytic converters: Contributions from material flow analysis and circularity indicators. Journal of Industrial Ecology. 2019; 1- 16. doi.org/10.1111/jiec.12852

- Evaluation of the environmental and economic repercussions due to the leakages of platinum for European stakeholders, by comparison to the potential reuse of secondary platinum.

- Application of circularity indicators on the end-of-life value chain (collection, pre-processing and end-processing) to get an augmented knowledge of improvement areas on the circularity performance, as well as to track progress and assess the impacts of potential action levers.

\section{MATERIALS AND METHODS}

\subsection{Research methodology}

The material flow analysis (MFA) is the main methodology used here to provide meaningful insights to the objectives aforementioned. The research process to perform proper MFA implies literature review, data collection, hypothesis and extrapolation development, crossing different data sources, and therefore uncertainty analysis for sensible information flows. The rationale having selected the MFA methodology is detailed in this section, through a synthesized literature survey.

Material flow analysis, also known as material flow accounting, is a systematic assessment of the flows and stocks of materials within a system defined in space and time (Brunner and Rechberger, 2003). It has become one of the most acknowledged tools in the industrial ecology field to control material use and industrial processes, as well as to create loop-closing industrial practices (Takeyama et al. 2016). MFA is thus an efficient tool to map material flows and stocks across the economy (Nansai et al. 2014; Bollinger, 2012; Mathieux and Brissaud, 2010). For instance, Nansai et al. (2014) quantified the global transfer of three critical metals (neodymium, cobalt, and platinum) by means of MFA, using trade data and the metals contents of trade commodities. In fact, MFA allows to quantify the material efficiency and the improvement potential of the value chain associated to a product or material. As reviewed by Moriguchi and Hashimoto (2016), MFA has often been used to capture flows of valuable resources contained in end-of-life vehicles, such as aluminum, steel, copper, lead, and zinc, or even to analyze lithium-ion battery waste flows from electric vehicles in the future. On this basis, MFA can notably be useful for decisions concerning waste management, to inform both policy, research and managerial choices (Bellstedt, 2015).

Furthermore, the promising bridge and association between MFA and the CE has been mentionned by Bellstedt (2015) in the way the CE provides a sense of purpose and direction to the analysis, while in turn MFA generates transformational knowledge for a transition to a more CE. MFA is thus an appropriate basis for monitoring the physical flows during the CE implementation (Kalmykova et al. 2017). In comparison with emergy analysis and input-output analysis, the MFA method allows addressing more comprehensive and integrated representation of materials/products flow and stock externalities, in addition of being the more mature approach. Interestingly MFA models allow also the identification of actors managing the flows. For instance, Diener and Tillman (2016) used MFA to create a map of the system, to estimate the physical flows in the system, in order to finally identify opportunities for an improved end-of-life management. Yet, to Bellstedt (2015) product-specific MFAs are at present barely developed, excepted for a limited number of products covered by regulations.

In this study, the MFA methodology is applied to quantify and break the hurdles for advancing a CE of platinum contained in catalytic converters, notably for diesel-powered vehicles in Europe. The MFA was conducted in two phases using STAN (subSTance flow ANalysis) software (Cencic and Rechberger, 2008) with the consideration of data uncertainties. First, the value chain and related stakeholders are mapped out in a MFA-like model to both facilitate the assessment of stocks and flows, and get a comprehensive view of potential action levers and resources. Then, two MFA are completed: (i) one general MFA, and (ii) one sector-specific MFA, drawing a distinction between the fate of platinum from (a) light-duty vehicles, under the ELV Directive 2000/EC/53, and (b) heavyduty and off-road vehicles, not subject to such a regulatory framework.

Brunner and Rechberger (2003) provide key guidelines to perform a consistent MFA, striving for transparency and manageability. In a nutshell, conducting a proper MFA consists of the following steps: 
To cite this version: Saidani, M, Kendall, A, Yannou, B, Leroy, Y, Cluzel, F. Closing the loop on platinum from catalytic converters: Contributions from material flow analysis and circularity indicators. Journal of Industrial Ecology. 2019; 1- 16. doi.org/10.1111/jiec.12852

- Identifying the material(s) of interest: Platinum from catalytic converters;

- Determining the system boundaries: The spatial system boundary is the EU-28 and the system boundary in time is the year 2017;

- Identifying the activities or processes of interest: The main lifecycle stages of the European value chain of platinum contained in catalytic converters (see section 3.1. for more details);

- Calculation of the stock and flows: This step is entirely described and illustrated in section 3.2.

For better transparency regarding the present scope of analysis, it is valuable to remind that the core structure and function of the catalytic converter is composed of three main components: (i) the canning, also called the converter housing; (ii) the catalyst support, also called the substrate or ceramic brick in cordierite; and (iii) the coating, also called the catalyst washcoat. The platinum contained in the coating is the only material considered in this study. The end-of-life pathways of the steel from the canning (cut then recycled in still mill) or of the ceramic (shredded then reused in cement factory, once the platinum and other PGM, if any, are separated from the ceramic) are out of the scope of the present study.

\subsection{Data collection and uncertainty analysis}

To complete the expected MFA, an in-depth cross analysis of numerous data sources - i.e. technical, industrial, and market reports, European statistics, as well as academic publications and communications from environmental or governmental agencies - has been conducted. Actually, complementary publications from different fields - i.e. from industrial ecology e.g. Hagelüken et al. (2016), from industrial engineering e.g. Fornalczyk and Saternus (2013), and from chemical science e.g. Pospiech (2012) - have been used.

Some data are considered reliable as they are derived from official statistics - e.g. Eurostat (2017), JM (2017), and ICCT (2016). Yet, some assumptions and extrapolations have to be made to determine the value of certain flows for the year 2017 at the European scale. As an illustration, the CC recycling market and associated collection process are highly opaque (see sub-section 3.1 for more details), and thus, it can be difficult to judge statistics without being an insider or industrialist of this sector. For this reason, uncertainty analysis has been considered to support the transparency and reliability of the results. Data quality assessment is indeed encouraged by the EC (2015), recommending systematically the definition and use of data quality indicators (DQI) e.g. in a context of Product Environmental Footprint (Poolsawad et al. 2017). Indeed, sustainability problems are usually difficult to manage due to the presence of complexity along with a series of uncertainties and vagueness (Sabaghi et al. 2016). The STAN software, used to perform the MFA, allows the consideration of data uncertainties (Cencic and Rechberger, 2008) and provides a data reconciliation feature (Cencic, 2016). In the STAN methodology, it is assumed that uncertain quantities are normally distributed, given by their mean value and standard deviation.

Leroy (2009) described different methods and procedures for data quality management in life cycle inventory. The use of a pedigree matrix to evaluate the quality of a data is particularly recommended. In the pedigree matrix proposed by Weidema and Wesnaes (1996), each input parameter is evaluated from 1 (good) to 5 (bad) on five quality criteria (reliability, completeness, temporal correlation, geographical correlation, and technological correlation) arguing these criteria are independent and sufficient to characterize information.

A more pragmatic approach was developed by BIO by Deloitte (2015) to give a quality assessment of the results of the MSA (see Table 1) in order to ensure the reliability and consistency of these results. According to the authors, this approach has the advantage: "to be very simple to implement, in order not to make more complex the development of the MSA; to allow the tracking and the transparent assessment of the robustness of the results provided for each parameter of the MSA; to highlight important missing information or results of inferior quality with the purpose to stimulate institutions and stakeholders to close the information gaps by carrying out studies or data gathering activities".

Even the approach developed by pedigree matrix proposed by Weidema and Wesnaes (1996) is now widely used in the LCA field, it was not straightforward in the present case to determine with accuracy and consistency all the criteria pedigree matrix for all the different flows, regarding the variety of data sources. As such, the uncertainty levels of the input data are quantified using the pragmatic approach proposed by BIO by Deloitte (2015). More precisely, for each data used and/or 
parameter calculated for a flow of the MFA, a quality score from 1 to 4 is attributed according to the criteria presented in Table 1. Following the principle of a pedigree matrix, the data quality indicators are transformed into estimates of the uncertainty - i.e. the value of the standard deviation around the mean value - which increases according to how low the data quality is.

Table 1: Data quality score and associated uncertainty values (inspired by: BIO by Deloitte, 2015)

\begin{tabular}{|c|c|c|c|c|c|}
\hline $\begin{array}{l}\text { Sources } \\
\text { of data }\end{array}$ & $\begin{array}{l}\text { Criteria for the } \\
\text { quality score of the } \\
\text { data used }\end{array}$ & $\begin{array}{l}\text { Criteria for the quality } \\
\text { score of the parame- } \\
\text { ters calculated }\end{array}$ & $\begin{array}{l}\text { Quality } \\
\text { score }\end{array}$ & $\begin{array}{l}\text { Uncertainty val- } \\
\text { ues for the MFA } \\
\text { stocks and flows }\end{array}$ & $\begin{array}{l}\text { Stocks and flows } \\
\text { concerned (see } \\
\text { Table 2) }\end{array}$ \\
\hline \multirow{2}{*}{$\begin{array}{l}\text { Data pub- } \\
\text { lished or } \\
\text { given } \\
\text { from ex- } \\
\text { perts }\end{array}$} & $\begin{array}{l}\text { Direct use of data } \\
\text { from a source }\end{array}$ & $\begin{array}{l}\text { Using only data from } \\
\text { sources }\end{array}$ & 4 & No uncertainty & 11 \\
\hline & $\begin{array}{l}\text { Basic extrapolation } \\
\text { of data from a } \\
\text { source }\end{array}$ & $\begin{array}{l}\text { Using at least one ex- } \\
\text { trapolation of data } \\
\text { from a source }\end{array}$ & 3 & $\begin{array}{l}\text { Standard devia- } \\
\text { tion }=10 \% \text { of the } \\
\text { mean value }\end{array}$ & $\begin{array}{l}\mathrm{F} 1, \mathrm{~F} 2, \mathrm{R} 1, \mathrm{~L} 3, \\
\mathrm{~L} 4, \mathrm{E} 1\end{array}$ \\
\hline \multirow[t]{2}{*}{$\begin{array}{l}\text { Estima- } \\
\text { tion or hy- } \\
\text { pothesis }\end{array}$} & $\begin{array}{l}\text { Estimation of data } \\
\text { based on known } \\
\text { facts }\end{array}$ & $\begin{array}{l}\text { Using at least one es- } \\
\text { timation of data } \\
\text { based on known facts }\end{array}$ & 2 & $\begin{array}{l}\text { Standard devia- } \\
\text { tion }=20 \% \text { of the } \\
\text { mean value }\end{array}$ & $\begin{array}{l}\text { I2, I3, I4, R2, R3, } \\
\text { E2, L2, F3, F4, } \\
\text { P3 }\end{array}$ \\
\hline & Hypothesis & $\begin{array}{l}\text { Using at least one hy- } \\
\text { pothesis }\end{array}$ & 1 & $\begin{array}{l}\text { Complete sensi- } \\
\text { tivity analysis } \\
\text { performed }\end{array}$ & L1 \\
\hline
\end{tabular}

On this background, the MFA modeling and computation can be now properly conducted. First, a graphical model of the MFA is built (flows, processes, systems boundaries, text fields) representing the platinum value chain for catalytic converters in the EU. Then, known data (mass flows, stocks and transfer coefficients) are directly assigned in the MFA model for flows with no uncertainty on it, e.g. high quality data provided by JM (2017). For each flow estimated through combination of uncertain data, assumptions and/or extrapolations, a mean value and associated standard deviation are defined according to the data quality model proposed by BIO by Deloitte (2015). Finally, the data reconciliation functionality of STAN is applied to adjust all stock and flow values in accordance with the mass balance, and to determine the most plausible values of unknown quantities (missing flows, changes in stocks). All data sources used, mean values and standard deviations calculated for each stock and flow are reported in section 3.2.

\section{RESULTS}

\subsection{Visualization of the value chain}

The European value chain of platinum contained in catalytic converters includes the following key processes, as illustrated in Table 2: production, use and stockpile, collection, pre-processing and refining. The dotted line marks the system boundary of the system i.e. the stocks and flows occurring in the EU-28. The graphical MFA-like model is the first stage of the MFA methodology conducted here to capture visually the value buckets within the value chain. It provides indeed a good knowledge and comprehensive vision of the current value chain and mechanisms of the platinum contained in catalytic converters (potential collection, imports, exports, end-of-life process). Moreover, in Table 2, key stakeholders of this value chain are mapped out and assigned to each process. An estimate of the order of magnitude on the number of actors is also informed, as well as their geographical locations. Examples of companies playing a key role are also given. Interestingly, the top and the bottom of the catalytic converter value chain are well-defined, delimited and dominated by a few global and European players. Some of the key manufacturers and refiners operating in the European market are Johnson Matthey, BASF or Umicore. On the contrary, the use phase involves a wider variety of actors disseminated all across Europe, making the collection process difficult, not sufficiently well-established and controlled especially for the heavy-duty and off-road vehicles. 
Table 2: Value chain of the platinum from catalytic converters in the EU-28

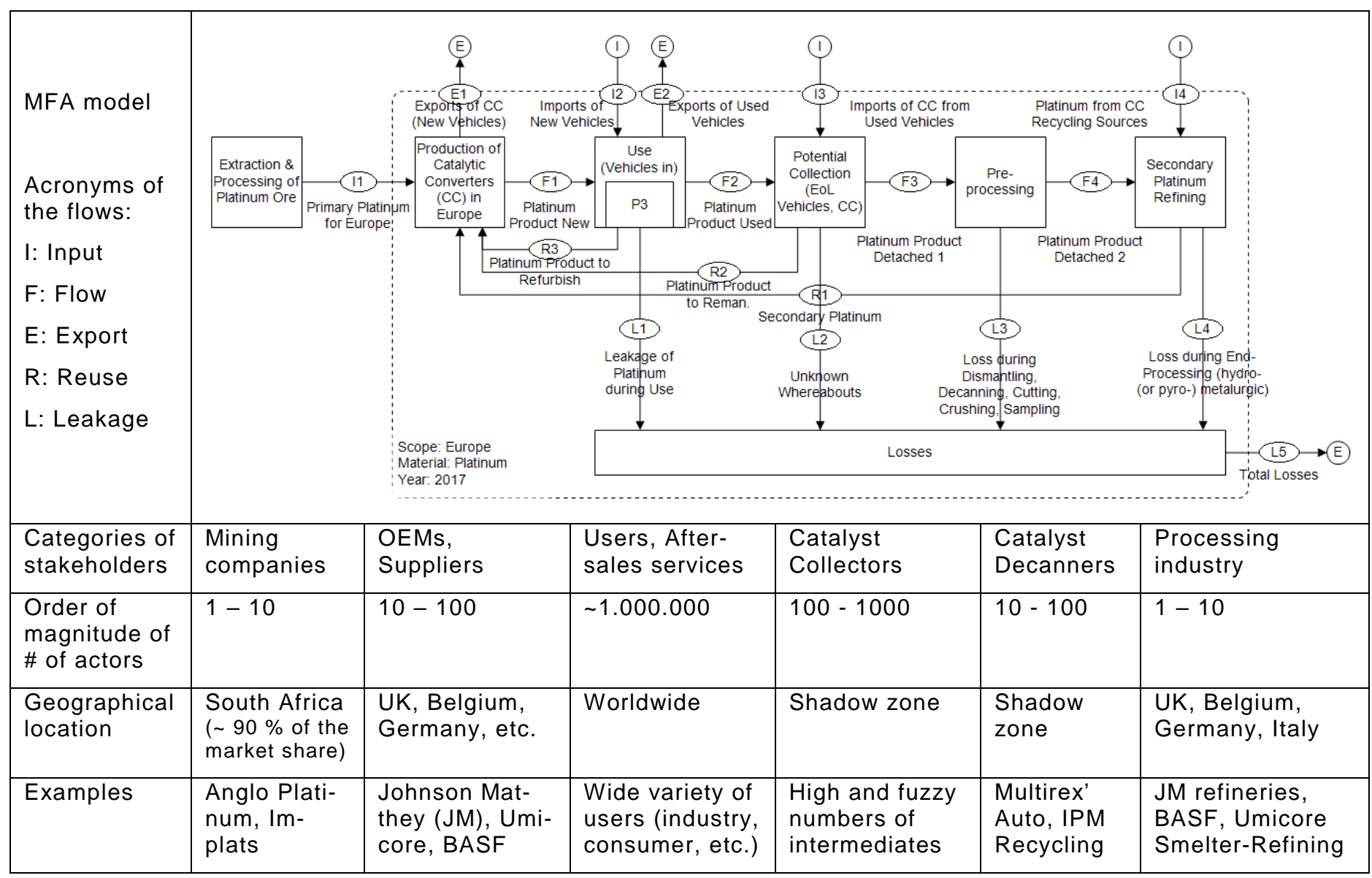

\subsection{Calculation of stock and flows}

The description of the MFA flows and stocks, illustrated in Table 2, is now detailed through Table 3, including: name, value, data sources and quality assessment. As input information of the MFA model, the following stocks and flows have been assigned, either directly (based on known data with no uncertainty on it: 11) or after calculation (based on extrapolation of data from a source, or estimation of data based on known facts, with associated uncertainty according to the Table 1: F1, F2, R1, L3, L4, E1, I2, I3, R2, R3, E2, L2, and P3). Importantly, for the flow I1, which has the highest uncertainty regarding the values found in different publications, an independent uncertainty analysis have been performed, resulting in a mean value of 3.5 tons with a standard deviation of 1.3 tons (normally distributed), as detailed in Appendix A. Then, for the flows F3, F4, and I4, and the accumulation in stock P3, the data reconciliation functionality of STAN, coupled with the transfer coefficients associated to the flows L3 and L4, have been deployed to determine the most plausible values of these missing quantities. Finally, all stock and flow values and uncertainties have been adjusted in accordance with the mass balance and the nonlinear data reconciliation algorithm implemented in STAN use (Cencic, 2016). 
Table 3: Description of stocks and flows: values, data sources and uncertainties

\begin{tabular}{|c|c|c|c|c|c|}
\hline \multirow[t]{2}{*}{$\begin{array}{l}\text { Flow } \\
\#\end{array}$} & \multirow[t]{2}{*}{ Flow name } & \multirow[t]{2}{*}{ Mean Value } & \multirow[t]{2}{*}{ Data sources } & \multicolumn{2}{|c|}{$\begin{array}{l}\text { Data quality assessment (BIO by } \\
\text { Deloitte, 2015) }\end{array}$} \\
\hline & & & & $\begin{array}{l}\text { Quality score } \\
\text { of the data } \\
\text { used (overall) }\end{array}$ & $\begin{array}{l}\text { Quality score } \\
\text { of the parame- } \\
\text { ter calculated }\end{array}$ \\
\hline 11 & $\begin{array}{l}\text { Primary platinum for } \\
\text { the production of cat- } \\
\text { alytic converters (CC) } \\
\text { in Europe }\end{array}$ & $\begin{array}{l}\text { Input data (given): } 36.6 \\
\text { tons (including light- } \\
\text { duty, heavy-duty and } \\
\text { off-road vehicles) }\end{array}$ & JM, 2017 & 4 & $\begin{array}{l}\text { n/a (not appli- } \\
\text { cable) }\end{array}$ \\
\hline 12 & $\begin{array}{l}\text { Imports of new } \\
\text { vehicles with catalytic } \\
\text { converters (CC) }\end{array}$ & $\begin{array}{l}\text { Input data (calculated): } \\
6.8 \text { tons }\end{array}$ & $\begin{array}{l}\text { ACEA, } 2017 \\
\text { ICCT, 2016 } \\
\text { Saidani, 2015 } \\
\text { Belcastro, 2012 } \\
\text { Ravindra et al. } 2004 \\
\text { Amatayakul and } \\
\text { Ramnas, 2001 }\end{array}$ & 2 & 2 \\
\hline 13 & $\begin{array}{l}\text { Imports of CC from } \\
\text { used vehicles }\end{array}$ & $\begin{array}{l}\text { Input data (calculated): } \\
0.2 \text { tons }\end{array}$ & $\begin{array}{l}\text { Eurostat, } 2017 \\
\text { Lorz, } 2017 \\
\text { Saidani, } 2015 \\
\text { Belcastro, } 2012 \\
\text { Ravindra et al. } 2004 \\
\text { Amatayakul and } \\
\text { Ramnas, } 2001\end{array}$ & 2 & 2 \\
\hline 14 & $\begin{array}{l}\text { Platinum from CC re- } \\
\text { cycling sources extra } \\
\text { from EU-28 }\end{array}$ & $\begin{array}{l}\text { Calculated ( } 2.9 \text { tons) } \\
\text { through the data recon- } \\
\text { ciliation algorithm of } \\
\text { STAN software and } \\
\text { mass balance }\end{array}$ & No data found & $n / a$ & 2 \\
\hline F1 & $\begin{array}{l}\text { Platinum used for } \\
\text { production of new CC }\end{array}$ & $\begin{array}{l}\text { Input data (calculated): } \\
38.7 \text { tons }\end{array}$ & $\begin{array}{l}\text { ACEA, } 2017 \\
\text { JM, } 2017 \\
\text { ICCT, } 2016 \\
\text { Saidani, } 2015 \\
\text { Weiland, } 2014 \\
\text { Belcastro, 2012 } \\
\text { Ravindra et al. } 2004 \\
\text { Amatayakul and } \\
\text { Ramnas, 2001 }\end{array}$ & 3 & 3 \\
\hline $\mathrm{F} 2$ & $\begin{array}{l}\text { Platinum content in } \\
\text { used CC }\end{array}$ & $\begin{array}{l}\text { Calculated, based on } \\
\text { the number of vehicles } \\
\text { reaching their end-of- } \\
\text { life, and the average } \\
\text { quantity of platinum in } \\
\text { such vehicles (see Ap- } \\
\text { pendix A) }\end{array}$ & $\begin{array}{l}\text { ACEA, } 2017 \\
\text { Eurostat, } 2017 \\
\text { ICCT, } 2016 \\
\text { Saidani, } 2015 \\
\text { Belcastro, } 2012 \\
\text { Ravindra et al. } 2004 \\
\text { Amatayakul and } \\
\text { Ramnas, 2001 }\end{array}$ & 3 & 3 \\
\hline F3 & $\begin{array}{l}\text { Platinum content in } \\
\text { recovered CC }\end{array}$ & $\begin{array}{l}\text { Calculated, through the } \\
\text { data reconciliation algo- } \\
\text { rithm of STAN software } \\
\text { and mass balance }\end{array}$ & $\begin{array}{l}\text { Various } \\
\text { (see F2, I3, R2, L2) }\end{array}$ & 2 & 2 \\
\hline F4 & $\begin{array}{l}\text { Platinum content } \\
\text { from CC entering the } \\
\text { refining center }\end{array}$ & $\begin{array}{l}\text { Calculated, through the } \\
\text { data reconciliation algo- } \\
\text { rithm of STAN software } \\
\text { and mass balance }\end{array}$ & $\begin{array}{l}\text { Various } \\
\text { (see F3, L3) }\end{array}$ & 2 & 2 \\
\hline R1 & $\begin{array}{l}\text { Secondary platinum } \\
\text { from recycled CC }\end{array}$ & $\begin{array}{l}\text { Input data (calculated) } \\
12.6 \text { tons }\end{array}$ & $\begin{array}{l}\text { JM, } 2017 \\
\text { Eurostat, } 2017\end{array}$ & 3 & 3 \\
\hline $\mathrm{R} 2$ & $\begin{array}{l}\text { Platinum from used } \\
\text { CC (to reman.) }\end{array}$ & $\begin{array}{l}\text { Input data (calculated): } \\
1.5 \text { tons }\end{array}$ & $\begin{array}{l}\text { JM, } 2017 \\
\text { ICARRE95 }\end{array}$ & 2 & 2 \\
\hline R3 & $\begin{array}{l}\text { Platinum from sec- } \\
\text { ond-hand CC }\end{array}$ & $\begin{array}{l}\text { Input data (calculated): } \\
1.5 \text { tons }\end{array}$ & $\begin{array}{l}\text { JM, } 2017 \\
\text { ICARRE95 }\end{array}$ & 2 & 2 \\
\hline L1 & $\begin{array}{l}\text { Leakage of platinum } \\
\text { during use }\end{array}$ & $\begin{array}{l}\text { Input data (calculated): } \\
3.5 \text { tons } \\
\text { See Appendix A. }\end{array}$ & $\begin{array}{l}\text { Bardi and Caporali, } \\
2014 \\
\text { Kalavrouziotis and } \\
\text { Koukoulakis, } 2009 \\
\text { Barbante et al. } 2001 \\
\text { Artelt et al. } 1999, \ldots \\
\end{array}$ & 1 & 1 \\
\hline
\end{tabular}




\begin{tabular}{|c|c|c|c|c|c|}
\hline L2 & $\begin{array}{l}\text { Unknown wherea- } \\
\text { bouts (non-controlled } \\
\text { exports, illegal mar- } \\
\text { ket, etc.) }\end{array}$ & $\begin{array}{l}\text { Input data (calculated): } \\
9.2 \text { tons }\end{array}$ & $\begin{array}{l}\text { Eurostat, } 2017 \\
\text { Lorz, } 2017\end{array}$ & 2 & 2 \\
\hline L3 & $\begin{array}{l}\text { Loss during pre-pro- } \\
\text { cessing }\end{array}$ & $\begin{array}{l}\text { Calculated, based on } \\
\text { transfer coefficient: } \\
10 \% \text { of platinum from } \\
\text { pre-processing }\end{array}$ & $\begin{array}{l}\text { Hagelüken et al. } \\
2016 \\
\text { Fornalczyk and } \\
\text { Saternus, } 2013 \\
\text { Pospiech, } 2012\end{array}$ & 3 & 3 \\
\hline L4 & $\begin{array}{l}\text { Loss during end-pro- } \\
\text { cessing }\end{array}$ & $\begin{array}{l}\text { Calculated, based on } \\
\text { transfer coefficient: } \\
3.5 \% \text { of platinum from } \\
\text { end-processing }\end{array}$ & $\begin{array}{l}\text { Hagelüken et al. } \\
2016 \\
\text { Fornalczyk and } \\
\text { Saternus, } 2013 \\
\text { Pospiech, } 2012\end{array}$ & 3 & 3 \\
\hline E1 & $\begin{array}{l}\text { Exports of CC from } \\
\text { European market }\end{array}$ & $\begin{array}{l}\text { Input data (calculated): } \\
=13.5 \text { tons }\end{array}$ & ACEA, 2017 & 3 & 3 \\
\hline E2 & $\begin{array}{l}\text { Exports of used ve- } \\
\text { hicles with CC }\end{array}$ & $\begin{array}{l}\text { Input data (calculated): } \\
5.5 \text { tons }\end{array}$ & $\begin{array}{l}\text { Lorz, } 2017 \\
\text { Eurostat, } 2017\end{array}$ & 2 & 2 \\
\hline P3 & $\begin{array}{l}\text { Movements in stocks } \\
\text { (Platinum content } \\
\text { from CC in use in Eu- } \\
\text { rope) }\end{array}$ & $\begin{array}{l}\text { Input data (calculated): } \\
570 \text { tons }\end{array}$ & $\begin{array}{l}\text { ACEA, } 2017 \\
\text { JM, } 2017 \\
\text { ICCT, 2016; Weiland, } \\
2014\end{array}$ & 2 & 2 \\
\hline
\end{tabular}

\subsection{New quantitative insights from MFA}

The computed MFA of the platinum contained in catalytic converters in the EU-28 for the 2017 year is displayed in Figure 1, including all quantitative stocks and flows with associated uncertainties, following Sankey diagram principles for platinum mass - i.e. the thickness of the lines indicates the relative magnitude of the flows - and showing platinum losses occurring all along the value chain.

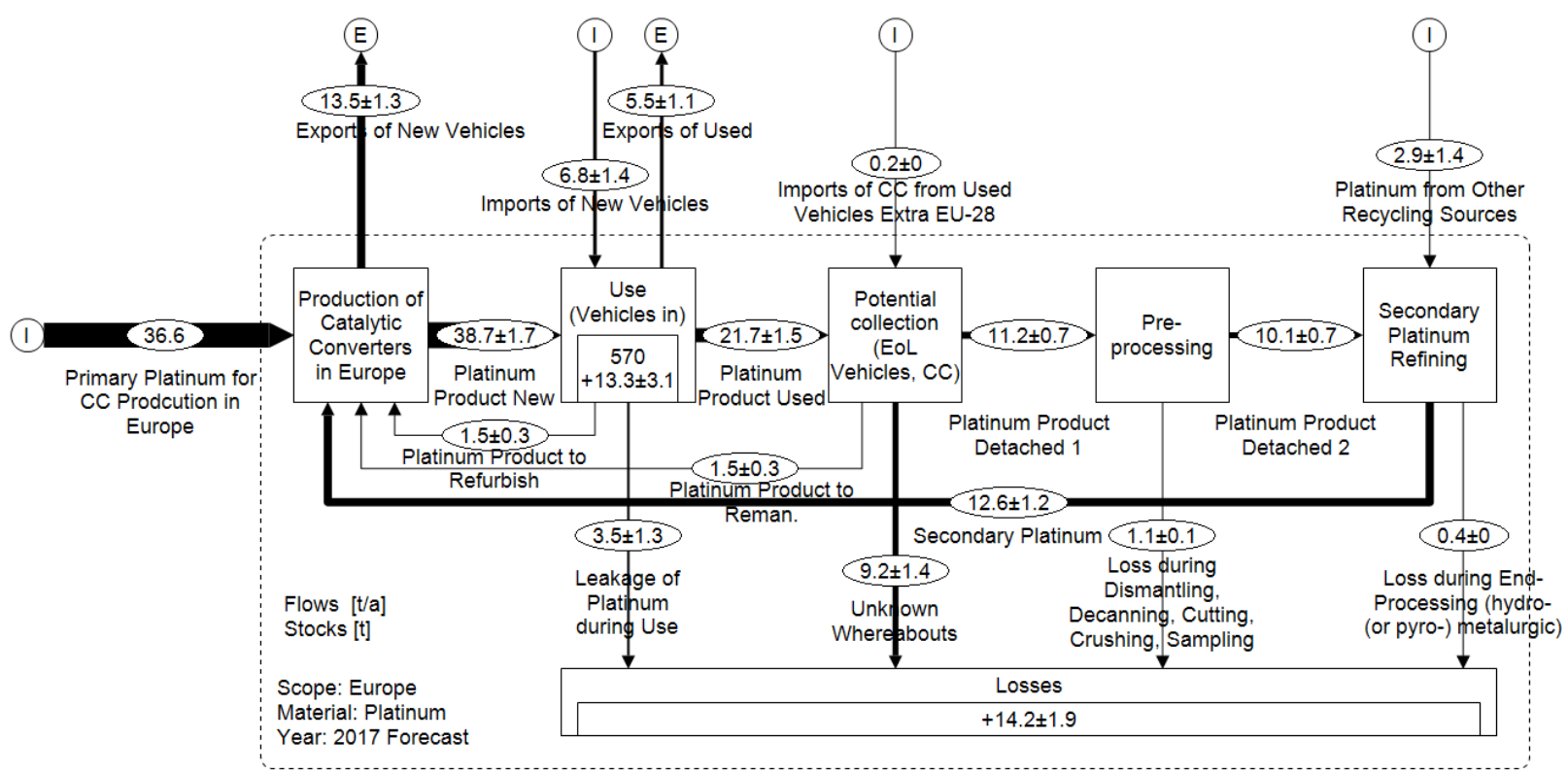

Figure 1: MFA of platinum from catalytic converters (EU-28, 2017, with uncertainties)

A differentiation is then made between platinum flows belonging to whether light-duty vehicles (flows in blue) or heavy-duty and off-road vehicles (flows in purple), as illustrated in Figure 2. Note that no demarcation was possible to make for the three flows in grey, and for readability reasons, the uncertainties values were not displayed in the second MFA. 


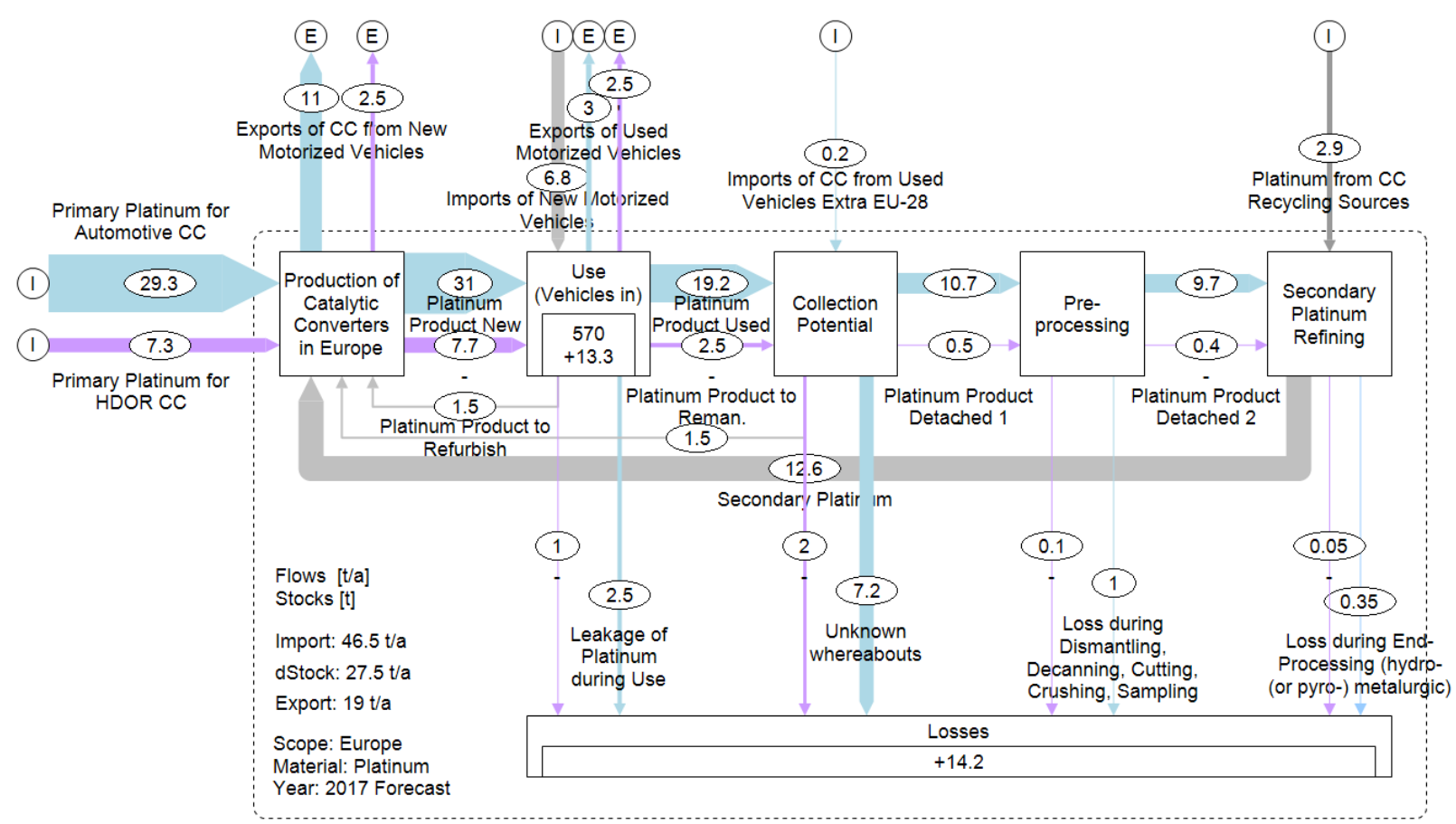

Figure 2: Demarcation between light (blue) and heavy vehicles (purple) platinum flows

Consequences and repercussions of the losses and leakages of platinum all along the value chain are discussed in section 4 . In fact, main environmental and economic value buckets related to the potential augmented use of secondary platinum are highlighted. Interestingly, a focus is also made on the intrinsic circularity performance of this value chain through the application of circularity indicators.

\section{DISCUSSION}

\subsection{Comparison of the MFA results with previous studies}

First, before advancing the interpretation of our findings, some validation elements of the computed MFA are discussed here to ensure an augmented transparency and trustworthiness of the discussion section.

The order of magnitude of the key and most sensitive flows of the present MFA are compared with the values of prior platinum MFA conducted in the EU, as summarized in Table 4. In fact, Saurat and Bringezu (2008) quantified the in-use stock of PGM (including platinum, palladium and rhodium) in catalytic converters to almost 500 tons for the year 2004, within the EU-25. More recently, BIO by Deloitte (2015) estimated the annual quantity of platinum added to stocks to be equivalent to 12 tons, with an in-use stock of 710 tons of platinum content all application being considered, for the year 2012 and within the EU-28. They also estimated the losses due to in-use dissipation of platinum finished-products to be equal to 10.4 tons, including in this total not only the contributions from catalytic converters, but also industrial catalysts and medical applications.

On the other hand, Saurat and Bringezu (2008) showed that the environmental impacts created by secondary production of PGM in European refining center are significantly lower than those of primary production in South Africa, regarding emissions of sulphur carbon dioxide, as well as total material requirement. Eventually, our results are somehow in line with Hagelüken's estimation, predicting in 2006 that the annual losses from the autocatalyst lifecycle could reach 10 tonnes of PGM by 2020 (Hagelüken et al. 2009). 
To cite this version: Saidani, M, Kendall, A, Yannou, B, Leroy, Y, Cluzel, F. Closing the loop on platinum from catalytic converters: Contributions from material flow analysis and circularity indicators. Journal of Industrial Ecology. 2019; 1-16. doi.org/10.1111/jiec.12852

Table 4: Evolution and comparison of MFA related to PGM in the EU

\begin{tabular}{|c|c|c|c|}
\hline & $\begin{array}{l}\text { (Saurat and Bringezu, } \\
2008)\end{array}$ & (BIO by Deloitte), 2015 & Present MFA \\
\hline Time scope (year) & 2004 & 2012 & 2017 \\
\hline Geographical scope & $\begin{array}{l}\text { EU-25, plus Norway and } \\
\text { Switzerland }\end{array}$ & $\begin{array}{l}\text { EU-28, plus Norway and } \\
\text { Switzerland }\end{array}$ & $\begin{array}{l}\text { EU-28, plus Norway and } \\
\text { Switzerland }\end{array}$ \\
\hline Materials of interest & $\begin{array}{l}\text { Platinum, palladium, } \\
\text { rhodium }\end{array}$ & Platinum & Platinum \\
\hline Applications considered & Catalytic converters & $\begin{array}{l}\text { All applications being } \\
\text { considered }\end{array}$ & Catalytic converters \\
\hline In-use stock & $\sim 500$ tons & 710 tons & $\sim 580$ tons \\
\hline $\begin{array}{l}\text { Annual quantity added } \\
\text { to in-use stock }\end{array}$ & - & 12 tons & 13.3 tons \pm 3.1 tons \\
\hline In-use dissipation & - & 10.4 tons & 3.5 tons \pm 1.3 tons \\
\hline Functional recycling & 12 tons & 13.6 tons & 15.6 tons \pm 1.8 tons \\
\hline
\end{tabular}

\subsection{Circular economy performance of the value chain}

In addition to the MFA representation - highlighting the hotspots where platinum losses occur - the use of appropriate indicators can reveal opportunities to improve the sustainable performance of industrial ecosystems by displaying trends, scales and relations of materials consumed, dissipated and discarded (Wernick and Ausubel, 1995). Actually, the examination of MFA models is particularly relevant to establish the appropriateness of indicators for guiding managerial decisions intended to perpetuate resource movement in a CE (Franklin-Johnson et al. 2016). For example, in order to detect trends and critical points in the evolution of recycling chains, Dwek and Zwolinski (2015) showed it can be particularly relevant to employ performance ratios obtained from the flows of the MFA, such as: production efficiency, accumulation ratio, utilization efficiency, or secondary supply ratio. Graedel et al. (2011) provide a framework to measure the circularity performance of a metal within its related product value chain, at several levels of a MFA model, as illustrated through Figure 3. Recycling rates (RRs) are indeed often used as measure for the degree of circularity of an economy and can be splitted into different indicators (Haupt et al. 2017).

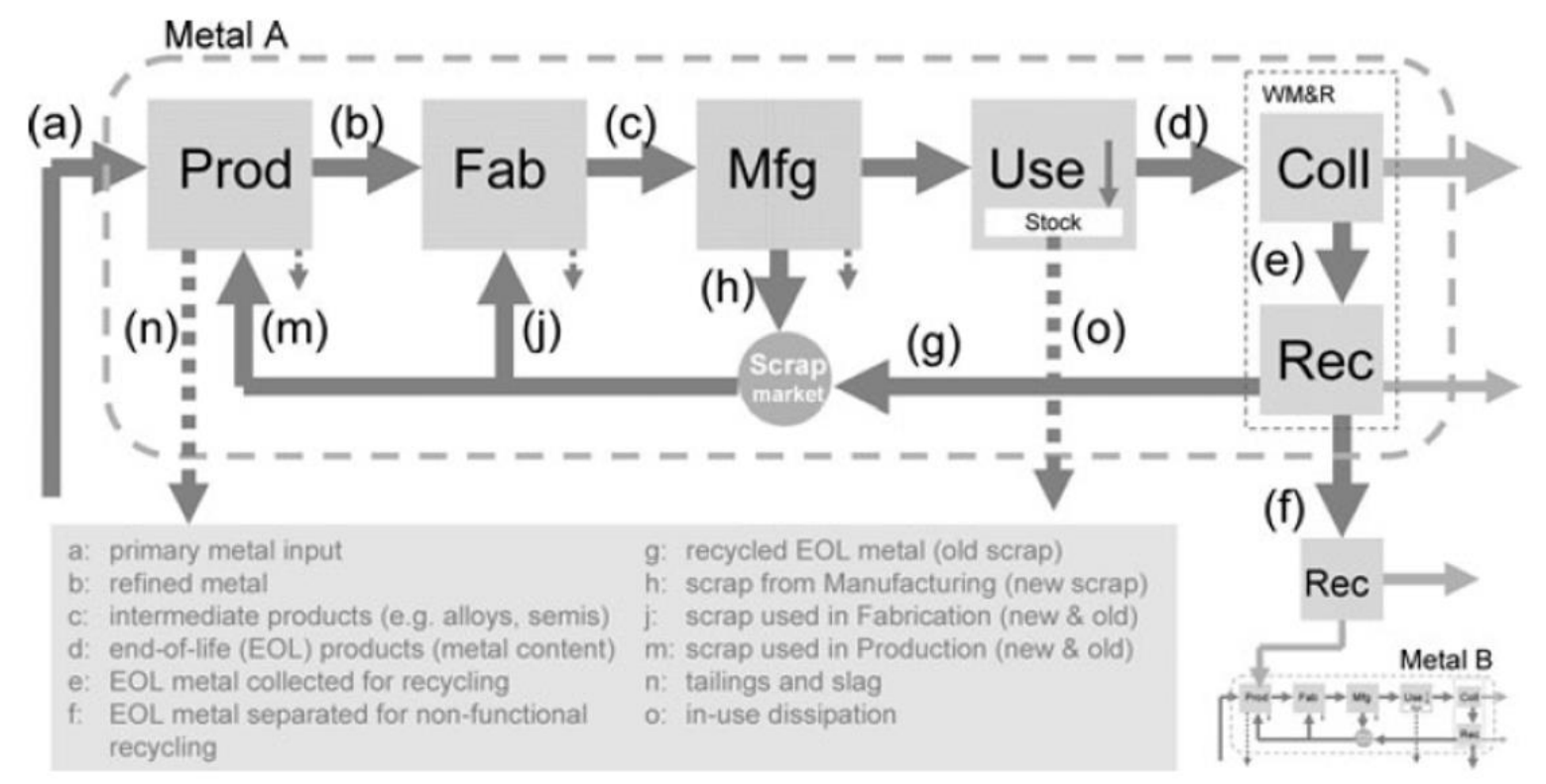

Figure 3: Framework to calculate circularity indicators based on MFA (source: Graedel et al. 2011) 
To cite this version: Saidani, M, Kendall, A, Yannou, B, Leroy, Y, Cluzel, F. Closing the loop on platinum from catalytic converters: Contributions from material flow analysis and circularity indicators. Journal of Industrial Ecology. 2019; 1- 16. doi.org/10.1111/jiec.12852

For instance, the old scrap collection rate $(\mathrm{CR})$, corresponding in the present case to the ratio of used catalytic converters effectively collected and entering the recycling process, is defined and calculated through the eq.1:

$$
C R=e_{1} / d=11.2 \pm 0.7+3.0 \pm 0.6 / 21.7 \pm 1.5+1.5 \pm 0.3=61 \% \pm 10
$$

The end-of-life process efficiency rate (EOL_ER), including here pre-processing and end-processing (i.e. refining), is given by the eq.2:

$$
E O L_{-} E R=g / e_{2}=12.6 \pm 0.7-2.9 \pm 1.4 / 11.2 \pm 0.7=87 \% \pm 2.4
$$

The end-of-life recycling rate $\left(E O L \_R R\right)$, referring here to functional or closed-loop recycling, and adapted according to the present MFA by considering both reuse and recycling (i.e. collection and processing yield), is given by the eq.3:

$$
E O L_{-} R R=\frac{g}{d}=12.6 \pm 0.7-2.9 \pm 1.4+3.0 \pm 0.6 / 21.7 \pm 1.5+1.5 \pm 0.3=55 \% \pm 16
$$

The recycled content $(R C)$, also known as end-of-life recycling input rate (EOL_RIR), measuring the ratio of secondary material used in the total material required for production (ISO 14044, EU-JRC 24708), is given by the eq.4:

$$
R C=j+m / a+j+m=12.6 \pm 1.2+3.0 \pm 0.6 / 36.6+12.6 \pm 1.2+3.0 \pm 0.6=30 \% \pm 4.5 \quad \text { (eq. } 4)
$$

The resource leakage from the system is also a meaningful indicator, determining the resource fraction that is leaving the product system and indicating therefore to what extent the loop is closed (Sinha et al. 2014). In our case, among the 36.6 tons of primary platinum demand for one year in Europe for autocatalyst applications (both in light-duty, heavy-duty and off-road vehicles), almost $40 \%$ of this quantity (14.2 tons) are lost this same year for the European economy (n.b. controlled imports and exports are well-balanced and thus not considered in this calculation).

These findings are well-aligned (same order of magnitude) with the value of recycling rates for PGM used in automotive catalysts (EOL_RR evaluated between 50 and $60 \%$ ) discussed by different authors (e.g. Hagelüken et al. 2016). Regarding the materials processed that come from recycled sources (referring here to the RC indicator), the economy is still far away from a true circular model as stated by Haas et al. (2015). Compared to other application fields using platinum, there is wide room for improvement in the autocatalyst sector from a CE perspective. For instance, as a comparison point, the platinum used in industrial processes (oil refining catalysts or glass industry) is operating in a closed-loop model with an end-of-life recycling rate (EOL_RR) higher than 90\% (Saurat and Bringezu, 2008; Hagelüken et al. 2016). Actually, the closed-loop systems of the oil refining catalysts and the glass industry, based on business-to-business cycles, lead to higher overall recycling rates than the ones from the open-loop system of the autocatalyst sector, which is based on business-to-consumer open cycle (Hagelüken et al. 2016). The present study confirms the two central reasons and obstacles in closing material cycles pinpointed by Haas et al. (2015): low end-of-life recovery rates, and in-use stocks accumulation. More interestingly, the results illustrate and put the emphasis on important facts reveals by Haupt et al. (2017) in the management and transition towards a more circular economy through recycling rates.

Indeed, comparing different recycling rates in a CE context at different scales - notably at the macro scale (regions, countries) of the CE implementation - Haupt et al. (2017) conclude that the currently used rates are not suitable as a performance indicator for a CE for three following key facts that are summarized and discussed hereafter:

- First, recycling and circularity rates do not share one common definition, e.g. at the European scale between member states. Because of the inconsistent definition of national recycling rates, some current rates used are not comparable. In fact, from a managerial and political standpoint, this variety of indicators can be confusing and is therefore not the most convenient way to define, communicate, and compare proper goals that every stakeholder can understand in the same way. For this reason, the CE action plan of the EC (2017) calls for harmonized indicators in order to manage the proposed targets for the recycling and reuse of materials - e.g. within the EU Raw Materials Information System (RMIS), launched at the end of 2017, to help coordinate other EUlevel data and information on raw materials (Mathieux et al. 2017). In line with Haupt et al. 2017, be clear on which rate (e.g. whether CR, EOL-RR or RC) is used, measured, and communicated is a key starting point to monitor the contribution of waste management to a CE in an integrated and 
meaningful manner. For instance, the RC appears as a good measure of the circular use of CRM in the contribution of recycling to meet the materials demand in the EU (Deloitte Sustainability, 2017).

- Second, collection rates $(\mathrm{CR})$ are often communicated, reflecting the input into the recycling system, but give neither an adequate picture of the available quantity of secondary resources produced that become effectively available (EOL_RR) nor indication about the final destination of these materials, showing the actual contribution of secondary materials to initial demand (like the $\mathrm{RC}$ indicator does). They fail as such to describe how much material is kept within material cycles (Haupt et al. 2017). Nevertheless, according to Linder et al. (2017), the proper combination of indicators should allow to measure circularity at complementary levels in a more nuanced manner. The use of a set of complementary indicators would indeed provide in-depth information, e.g. at different part of the value chain to prioritize and focus actions at more applied - i.e. technical and engineering - level.

- Third, today's recycling and circularity indicators focus mainly on the closing of material cycles, with the environmental benefits and impacts often remain unaddressed or decorrelated from the analysis. The comparison of lifecycle analysis results and recycling rates may also reveal potential trade-offs between the goals of resources recovery and lowering environmental impacts (Geissdoerfer et al. 2017). To bridge this gap, environmental and economic repercussions of the current leakages of platinum are discussed in the following sub-section, as well as improvement potentials to advance the circularity performance of the platinum value chain from catalytic converters in the EU.

\subsection{Environmental and economic implications}

The MFA results reveal an overall leakage of around 15 tons of Pt outside the European market in 2017, showing that considerable amounts of platinum could be recovered. In this section, this mass flow of platinum lost is translated and interpreted in terms of economic loss and environmental burden. Then, the implementation of potential improvement solutions are discussed.

According to Cullen (2017), two key guiding questions to assess the end-of-life options for materials or products from an environmental perspective are: "how much energy is required to restore the recovered material back to the desired material or product?" and, "how does this quantity compare with obtaining the desired material or product from virgin or primary sources?". Accordingly, Table 5 compares how much energy is required to produce one kilogram of platinum between its primary production in South African mines and its secondary production in state-of-the-art European refining centers, crossing several relevant data sources, as listed in Table 5 . As noticed by Glaister and Mudd (2010), non-negligible amounts of energy can be saved when platinum is recycled from used catalytic converters compared to raw production. In addition to the energy demand, the global warming potential (GWP) is the most used category to quantify the environmental impacts of PGM production (IPA, 2016). On this basis, the comparison of environmental impacts associated with platinum primary and secondary production is made in terms of energy consumption and GWP considering greenhouse gases (GHG) emissions, as given in Table 5.

Table 5: Environmental impact comparison between primary and secondary platinum

\begin{tabular}{|l|l|l|}
\hline & $1 \mathrm{~kg}$ of primary platinum & $1 \mathrm{~kg}$ of secondary platinum \\
\hline Energy demand (GJ / kg) & 200 & 10 \\
\hline GHG emissions ( $\mathrm{t} \mathrm{CO}_{2}$-eq/kg) & 40 & 2 \\
\hline Data sources and references & $\begin{array}{l}\text { Average values based on Bossi and } \\
\text { Gediga (2017), EASAC (2016), Mont- }\end{array}$ & $\begin{array}{l}\text { Average values based on JM (2017), } \\
\text { Bossi and Gediga (2017), EASAC } \\
\text { masson-Clair (2016), Cairncross } \\
\text { (2016), IPA (2016), Glaister and Mudd } \\
\text { (2014), Glaister and Mudd (2010). }\end{array}$ \\
\hline
\end{tabular}

As a result, comparing the environmental impact between primary and secondary production, it has been estimated that halving the leakages of platinum during the use and collection phases could prevent the energetic consumption of $1.3 \times 10^{3} \mathrm{TJ}$ and the greenhouse gases emissions of $2.5 \times 10^{2} \mathrm{kt} \mathrm{CO}_{2}$ eq. Yet, it must be kept in mind that such assumption would in a first time only improved the CR and EOL_RR values, and that to effectively mitigate the environmental and improve the circularity performance, the RC value as to be enhanced in the same way. This means 
the import of primary platinum should decrease in favour of the use of secondary refined platinum. Concretely, regarding the current annual import of platinum which is superior to 36 tons, such improvement potential would reduce the primary import by one quarter. Even if $100 \%$ of PGM from end-of-life products were to be recycled, however, the rate of secondary production input would still be limited, and primary PGM would still be needed. Primary and secondary production of PGM are indeed complementary and mutually dependent.

Additionally, knowing that the price of one kilogram of platinum fluctuates around $30 \mathrm{k} €$ (JM, 2017), these losses also result in high economic losses valuing up to hundreds of millions of euros for European stakeholders. Last but not least, the $C C$ attrition during its usage and the associated emissions of PGM particles in the environment - detailed in Appendix A - appears as non-negligible. Based on the scarce and dated publications in this regard, we encourage further research for a sound understanding of this phenomenon that can negatively impact human health (Wang and $\mathrm{Li}$, 2012). Bardi (2014) adds that, in such a case, PGM: "are potentially dangerous pollutants and have generated serious concerns regarding their effects on the environment and on human health"; and, "are dispersed in the environment at very low concentrations and are lost forever for all practical purposes".

\section{CONCLUSION}

\subsection{Opportunities for improvement}

Reviewing the publicly funded research project that are dealing with the CRM, Løvik et al. (2018) state that "more product-centric research considering a larger part of the materials cycle may facilitate recycling of a wider spectrum of metals" and that "particularly neglected topics include, recycling from end-of-life vehicles, design for recycling, and waste collection". Through this sectorand product-specific study focusing on the platinum contained in catalytic converters, our results contribute to fill such a gap pointed out by Løvik et al. (2018). Indeed, the present findings, by highlighting the underexploited value buckets on this specific value chain, orient towards suitable political, industrial and research actions to enhance the circularity performance of platinum from catalytic converters at the European scale.

Among the estimated 15 tons of platinum lost, approximately one quarter of the leakages is due to in-use dissipation, and two thirds are attributed to insufficient collections and unregulated exports. As a consequence, activating appropriate action levers to enhance the overall collection, recovery, and input rates of secondary platinum in the value chain is of the utmost importance in order to secure future and sustainable productions of new generations of CC and fuel cells. Moreover, the growing stockpile of Pt from CC in use (estimated at over 580 tons in 2017) is an additional hindrance to improve and increase the actual RC indicator.

Therefore, in-use $\mathrm{CC}$ represents an important and non-fully exploited value bucket which urges for better collection mechanisms. For instance, the ICARRE95 (Innovative Car Recycling 95\%) project highlights collect conditions to successfully close the loop: it includes sufficient volume collectable as well as a transparent network of end-of-life actors working together e.g. through constructors (e.g. Renault), collector (Synova recycling) authorized treatment facilities (Indra Automobile Recycling), catalytic converter recyclers (Hensel), refining center (Johnson Matthey), to the manufacturing of a new catalytic converter. To date, there has been much focus on the recovery channel of catalytic converters from light duty vehicles compared to heavy ones, not subject to end-of-life regulation. Yet, the end-of-life market in the heavy-duty and off-road vehicles sector presents a high economic potential (Saidani et al. 2018), particularly regarding the quantity of precious metals a single catalytic converter from one heavy vehicle can contain.

Some complementary ways of closing-the-loop on platinum from catalytic converters are discussed on the literature, but mostly at a qualitative and macro level, including recommendations such as "a betted enforcement of transboundary waste shipment rules to limit the export of genuine scrap cars" (Hagelüken, 2012). In accordance with Saurat and Bringezu (2008), such control could become part of an international material flow management system, through the cooperation of the automotive and recycling industries. Yet, the main challenge is still to keep track of PGM from 
exported vehicles (mainly to Eastern Europe and North Africa countries) and to manage the recovery of the parts after use in these regions as well.

More generally, Hagelüken (2012) depicts seven conditions for effective recycling of a product, material or metal: (1) technical recyclability of the material or metal combination; (2) accessibility of the relevant components; (3) economic viability, whether intrinsically or externally created; (4) collection mechanisms to ensure the product is available for recycling; (5) entry into the recycling chain and remaining therein up to the final step; (6) optimal technical and organizational set-up of this recycling chain; (7) sufficient capacity along the entire chain to make comprehensive recycling happen.

Eventually, note that the setup, uptake and implementation of such action levers (e.g. platform for an augmented collaboration between end-of-life actors, tools for a better traceability after sales, control instruments of mandatory recovery and recycling rates) will come with a cost that should be compared to the medium- and long-term benefits of a potential enhanced circularity of platinum for the involved stakeholders at the European scale. Thus, future work is encouraged to take into account the possible return on investment of the realization of more CE practices at different time scales, e.g. through a cost-benefit analysis.

\subsection{Next steps}

The MFA conducted here is the first step - providing a sound basis - of a multi-tool methodology presented at the ISIE-ISSST Joint Conference in 2017 (Saidani et al. 2017) to quantify the impact of potential CE strategies. Next steps include fuzzy cognitive mapping, structural analysis, scenarios generation and system dynamics to model, simulate and evaluate the effects of key action levers on the platinum value chain (mapped out in section 3 ), and its circularity performance (discussed in section 4 ):

- Fuzzy cognitive mapping, to make an inventory, map and link both influencing parameters and potential actions levers on a semi-quantitative causal graph;

- Structural analysis, to select key influence parameters and promising actions levers;

- Scenarios generation, to set up different relevant prospective scenarios;

- System dynamics, to simulate and compare the influence of selected actions levers on the CE performance, including stocks and flows, plus feedback loops (e.g. what will happen if a minimum mandatory recycling rate of HDOR vehicles is implemented?, or what if collection rate is improved by $10 \%$ or if design is modified for easy disassembly?).

The last step would consist on circling back to the present MFA, in order to report and compare the potential impacts on the current value chain and actors' network. As such, we are willing to demonstrate that the combination of MFA with complementary tools from engineering and social sciences could contribute in supporting industrial actors and decision makers to move towards more circular practices.

\subsection{Further perspectives}

The circularity of the CRM is essential for maintaining future and sustainable resource security in the European Union (EC, 2017). Yet reality is still far from being a perfect circular model (Haas et al. 2015). Our findings notably illustrate areas of work on the value chain of platinum contained in catalytic converter to improve its performance in a CE perspective. Securing the uncertain supply critical raw materials is crucial and requires a sound and consistently updated knowledge base (Mathieux et al. 2017).

Actually, in line with previous studies on this issue related specifically to PGM - e.g. Saurat and Bringezu (2008) providing a first overview of major platinum flows and processes in the EU, or Deloitte Sustainability (2017) providing also an important base of background information to help monitoring the circularity level of CRM in the EU - the present findings give an updated baseline to track progress on circularity performance, by providing a quantitative and localiz ed identification of the improvement opportunities on the European platinum value chain. The value buckets of such potential recovery of precious metals from catalytic converter in Europe, which are not fully exploited yet, have been highlighted. The environment plus economic implications for the European 
To cite this version: Saidani, M, Kendall, A, Yannou, B, Leroy, Y, Cluzel, F. Closing the loop on platinum from catalytic converters: Contributions from material flow analysis and circularity indicators. Journal of Industrial Ecology. 2019; 1- 16. doi.org/10.1111/jiec.12852

stakeholders have been extensively discussed. On this basis, the results can also be used independently to oriente both future research and political or industrial actions.

In parallel, and more globally to put things into perspectives, Løvik et al. (2018) delivered a comprehensive overview and detailed analysis of current developments and research projects on supply security of critical, rare earths and precious metals in Europe. They reviewed an extensive number of industrial activities, policies, and projects initiated in the EU to secure the future supply of CRM, distinguishing particularly, projects on primary supply, secondary supply, substitution and material efficiency, all along the lifecycle. For instance, in relation to PGM applications, the PLATIRUS project, funded by the European Commission (EC, 2016), aims at reducing the European deficit of PGM, by fostering the development of novel or improved secondary materials to PGM recovery supply chains from autocatalysts, e.g. by upscaling to industrial relevant levels a novel cost-efficient and miniaturized PGM recovery.

\section{REFERENCES}

ACEA-European Automobile Manufacturers' Association, 2017. Vehicles in use, Europe 2017. ACEA Report. Accessed on April 2018: http://www.acea.be/uploads/statistic_documents/ACEA_Report_Vehicles_in_use-Europe_2017.pdf

Alonso, E., Field, F. R., Kirchain, R. E., 2012. Platinum Availability for Future Automotive Technologies. Environmental Science \& Technology, 46 (23), 12986-12993.

Amatayakul, W, Ramnas O., 2001.Life cycle assessment of a catalytic converter for passenger cars. Journal of Cleaner Production, 9, 395-403.

Andersson, M., Ljunggren Söderman, M., Sandén, B. A., 2017. Are scarce metals in cars functionally recycled?, Waste Management, 60, 407-416.

Artelt, S., Kock, H., König, H.P., Levsen, K., Rosner, G., 1999 Engine dynamometer experiments: platinum emissions from differently aged three-way catalytic converters. Atmos Environ, 33, 3559-3567.

Barbante, C., Veysseyre, A., Ferrari, C., Van de Velde, K., Morel, C., Capodaglio, G., Cescon, P., Scarponi, G., Boutron, C., 2001. Greenland snow evidence of large scale atmospheric contamination for platinum, palladium, and rhodium. Environ Sci Technol, 35, 835-839.

Bardi, U., Caporali, S., 2014. Precious Metals in Automotive Technology: An Unsolvable Depletion Problem?. Minerals 4, 2, 388-398.

Belcastro, E. L., 2012. Life Cycle Analysis of a Ceramic Three-Way Catalytic Converter. Virginia Tech, Master Thesis.

Bellstedt, C., 2015. Material Flow Analysis for a Circular Economy Development: A Material Stock Quantification Method of Urban Civil Infrastructures with a Case Study of PVC in an Amsterdam Neighbourhood, Delft University of Technology, Master Thesis. English.

BIO by Deloitte. 2015. Study on Data for a Raw Material System Analysis: Roadmap and Test of the Fully Operational MSA for Raw Materials. Prepared for the European Commission, DG GROW.

Bollinger, L. A., Davis, C., Nikolić, I., Dijkema, G. P., 2012. Modeling metal flow systems. Journal of Industrial Ecology, 16 (2), 176-190.

Bossi, T., Gediga, J., 2017. The Environmental Profile of Platinum Group Metals, Johnson Matthey Technology Review, 61, (2), 111-121.

Brunner, P. H., Rechberger, H., 2003. Practical handbook of material flow analysis. CRC Press.

Cairncross, E. 2014. Health and environmental impacts of platinum mining. Report from South Africa, on behalf of PHM March 2014.

Cencic, O., 2016. Nonlinear data reconciliation in material flow analysis with software STAN. Sustainable Environment Research, 26, 291-298.

Cencic, O., Rechberger, H., 2008. Material Flow Analysis with Software STAN. Journal of Environmental Engineering and Management, 18 (1), 5.

CEPLACA, 1997. Assessment of environmental contamination risk by platinum, rhodium and palladium from automobile catalyst. Environmental and climate programme, European Union, ENV4-CT97-0518.

Cetim, 2017. Recyclage des métaux stratégiques. Note de veille technologique du Cetim. 
To cite this version: Saidani, M, Kendall, A, Yannou, B, Leroy, Y, Cluzel, F. Closing the loop on platinum from catalytic converters: Contributions from material flow analysis and circularity indicators. Journal of Industrial Ecology. 2019; 1-16. doi.org/10.1111/jiec.12852

CGE-Conseil général de l'économie, 2015. L'économie circulaire ou la compétition pour les ressources. La Documentation Française. French.

Cullen, J. M., 2017. Circular Economy: Theoretical Benchmark or Perpetual Motion Machine?. Journal of Industrial Ecology, 21, 483-486.

Deloitte Sustainability, British Geological Survey, Bureau de Recherches Geologiques et Minieres, Netherlands Organisation for Applied Scientific Research, 2017. Study on the review of the list of Critical Raw Materials - Criticality Assessment. Report prepared for the European Commission.

Diener, D., Tillman, A.-M., 2016. Scrapping steel components for recycling - Isn't that good enough? Seeking improvements in automotive component end-of-life. Resources, Conservation and Recycling, 110, 48-60.

Dwek, M., Zwolinski, P. 2015. How can we predict the evolution of recycling chains? Matériaux \& Techniques, $103,1$.

EASAC-European Academies Science Advisory Council, 2016. Priorities for critical materials for a circular economy. EASAC policy report 29, November 2016.

EC-European Commission, 2015. Closing the loop - An EU action plan for the Circular Economy. The Circular Economy Package Proposal. Communication from the Commission to the European Parliament, the Council, the European Economic and Social Committee and the Committee of the Regions. Brussels, Belgium.

EC-European Commission, 2016. PLATInum group metals Recovery Using Secondary raw materials, PLATIRUS Project H2020. Accessed on November 2018: http://cordis.europa.eu/project/rcn/206334_en.htm

EC-European Commission, 2017. Study on the review of the list of Critical Raw Materials, Critical Raw Materials Factsheets. June 2017, Luxembourg: Publications Office of the European Union.

EU-JRC 24708 EN. 2010. International reference life cycle data system (ILCD) handbook-General guide for life cycle assessment-Detailed guidance. First edit. European Commission Joint Research Center Institute for Environment and Sustainability. Luxembourg: Publications Office of the European Union.

Eurostat, 2017. End-of-life vehicles statistics. Accessed on April 2018: http://ec.europa.eu/eurostat/statistics-explained/index.php/End-of-life_vehicle_statistics

Franklin-Johnson, E., Figge, F., Canning, L., 2016. Resource duration as a managerial indicator for Circular Economy performance, Journal of Cleaner Production, 133, 589-598.

Fornalczyk, A., Saternus, M., 2013. Platinum recovery from used auto catalytic converters in electrorefining process. Metalurgija, 52, 2, 219-222.

Gaustad, G., Krystofik, M., Bustamante, M., Badami, K., 2018. Circular economy strategies for mitigating critical material supply issues. Resources, Conservation and Recycling, 135, 24-33.

Geissdoerfer, M., Savaget, P., Bocken, N.M., Hultink, E.J. 2017. The Circular Economy-A new sustainability paradigm? J. Clean. Prod., 143, 757-768.

Glaister, B. J., Mudd, G. M., 2010. The environmental costs of platinum-PGM mining and sustainability: Is the glass half-full or half-empty?. Minerals Engineering, 23 (5), 438-450.

Golunski, S., 2007. Why Use Platinum in Catalytic Converters? Platinum Metals Rev., 51 (3), 162.

Graedel, T.E., Allwood, J.M., Birat, J.-P., Buchert, M., Hagelüken, C., Reck, B.K., Sibley, S.F., Sonnemann, G., 2011. What Do We Know About Metal Recycling Rates? J. Ind. Ecol. 15, 355-366. 1125.

Groen, E.A., et al., 2017. Methods for global sensitivity analysis in life cycle assessment. Int J Life Cycle Assess, 22,

Haas, W., Krausmann, F., Wiedenhofer, D., Heinz, M., 2015. How Circular is the Global Economy?: An Assessment of Material Flows, Waste Production, and Recycling in the European Union and the World in 2005. J. Ind. Ecol. 19, 765777.

Hagelüken, C., 2012. Recycling the Platinum Group Metals: A European Perspective. Effective recycling systems for pgm-containing materials will ensure sustainable supply. Platinum Metals Rev., 56 (1). 41-69.

Hagelüken, C., 2014. Recycling of (critical) metals, in: G. Gunn (Ed.), Critical Metals Handbook, John Wiley \& Sons,

Hagelüken, C., Buchert, M., Ryan, P., 2009. Materials flow of platinum group metals in Germany. International Journal of Sustainable Manufacturing, 1, 330-346.

Hagelüken, C., Lee-Shin, J. U., Carpentier, A., Heron, C., 2016. The EU Circular Economy and Its Relevance to Metal Recycling. Recycling, 1, 242-253.

Haupt, M., Vadenbo, C., Hellweg, S., 2017. Do We Have the Right Performance Indicators for the Circular Economy?: Insight into the Swiss Waste Management System. Journal of Industrial Ecology, 21, 615-627. 
To cite this version: Saidani, M, Kendall, A, Yannou, B, Leroy, Y, Cluzel, F. Closing the loop on platinum from catalytic converters: Contributions from material flow analysis and circularity indicators. Journal of Industrial Ecology. 2019; 1- 16. doi.org/10.1111/jiec.12852

Helmers, E., 1997. Platinum Emission Rate of Automobiles with Catalytic Converters, Environmental Science and Pollution Research, 4, 100.

Hill, R.F., Mayer, W.J., 1977. Radiometric determination of platinum and palladium attrition from automotive catalysts. IEEE Trans. Nucl. Sci., 24, 2549-2554

ICCT-International Council on Clean Transportation, 2016. European Vehicles Market Statistics. Pocketbook 20152016.

IPA-International Platinum Group Metals Association, 2016. The LCA of platinum group metals. PGM fact sheets.

ISO-International Organization for Standardization. 2006. ISO 14044. Environmental management-Life cycle assessment-Requirements and guidelines. Geneva, Switzerland: International Organization for Standardization.

JM-Johnson Matthey, 2017. PGM Market Report May 2017, Summary of Platinum Supply \& Demand. Johnson Matthey Precious Metals Management.

Kalavrouziotis I.K., Koukoulakis P.H., 2009. The environmental impact of the platinum group elements (Pt, Pd, Rh) emitted by the automobile catalyst converters. Water Air Soil Pollut., 196, 393-402.

Kalmykova, Y., Sadagopan, M., Rosado, L., 2018. Circular economy - From review of theories and practices to development of implementation tools. Resources, Conservation and Recycling, 135, 190-201.

König, H. P., Hertel, R. F., Koch, W., Rosner, G., 1992. Determination of the platinum emissions from three-way catalyst-equipped gasoline engine. Atmos Environ, 26, 741-745.

Lapko, Y., Trianni, A., Nuur, C., Masi, D., 2018. In Pursuit of Closed-Loop Supply Chains for Critical Materials: An Exploratory Study in the Green Energy Sector. Journal of Industrial Ecology. doi:10.1111/jiec.12741

Leroy, Y., 2009. Développement d'une méthodologie de fiabilisation des prises de décisions environnementales dans le cadre d'ACV basée sur l'analyse et la gestion des incertitudes sur les données d'inventaires. Arts et Métiers ParisTech. $\mathrm{PhD}$ thesis. French.

Linder, M., Sarasini, S., van Loon, P., 2017. A Metric for Quantifying Product-Level Circularity. Journal of Industrial Ecology, 21, 545-558.

Lorz, B., 2017. The End-of -life vehicles (ELV) Directive and its implementation, European Commission, DG ENVUNECE Conference, Geneva, 20 March 2017.

Løvik, A. N., Hagelüken, C., Wäger, P., 2018. Improving supply security of critical metals: Current developments and research in the EU. Sustainable Materials and Technologies, 15, 9-18.

Mathieux, F., Ardente, F., et al., 2017. Critical Raw Materials and the Circular Economy - Background report. JRC Science-for-policy report. Publications Office of the European Union, Luxembourg, 2017.

Mathieux, F., Brissaud, D. 2010. End-of-life product-specific material flows analysis. Application to aluminum coming from end-of-life commercial vehicles in Europe. Resources, Conservation and Recycling, 55 (2), 92-105.

Matlab R2018a, Sensitivity Analysis. Accessed on April 2018: https://fr.mathworks.com/help/sldo/sensitivity-analysis.html

Montmasson-Clair, G., 2016. Mining, energy and low-carbon economy in South Africa: a platinum case study. 2016 TIPS Forum, Trade \& Industrial Policy Strategies, 14-15 June 2016.

Moriguchi Y., Hashimoto, S., 2016. Material Flow Analysis and Waste Management. Taking Stock of Industrial Ecology, Chapter 12, 247-262.

Nansai, K., et al., 2014. Global flows of critical metals necessary for low-carbon technologies: the case of neodymium, cobalt, and platinum. Environmental Science \& Technology, 48 (3), 1391-1400.

Nel, W. P., 2004. The diffusion of fuel cell vehicles and its impact on the demand for platinum group metals: research framework and initial results. International Platinum Conference "Platinum Adding Value". The South African Institute of Mining and Metallurgy.

Nuss, P., Eckelman M. J., 2014. Life Cycle Assessment of Metals: A Scientific Synthesis. PLOS ONE, 9 (7).

Palacios, M.A., Gómez, M., Moldovan, M, et al., 2000. Platinum-group elements: quantification in collected exhaust fumes and studies of catalyst surfaces. Sci Total Environ, 257, 1-15.

Poolsawad N. et al., 2017. Thai national life cycle inventory readiness for product environmental footprint. The International Journal of Life Cycle Assessment, 22 (11), 1731-1743.

Pospiech, B. 2012. Studies on platinum recovery from solutions after leaching of spent catalysts by solvent extraction. Physicochemical Problems of Mineral Processing, 48, 1, 239.

Ravindra, K., Bencs, L., Van Grieken, R., 2004. Platinum group elements in the environment and their health risk. Sci Total Environ, 318, 1-43. 
To cite this version: Saidani, M, Kendall, A, Yannou, B, Leroy, Y, Cluzel, F. Closing the loop on platinum from catalytic converters: Contributions from material flow analysis and circularity indicators. Journal of Industrial Ecology. 2019; 1- 16. doi.org/10.1111/jiec.12852

Sabaghi, M., Mascle, C., Baptiste, P., Rostamzadeh, R., 2016. Sustainability assessment using fuzzy-inference technique (SAFT): A methodology toward green products. Expert Syst. Appl. 2016, 56, 69-79.

Saidani, M., 2015. Life Cycle Assessment (LCA) of Selective Catalytic Reduction on Filter (SCRF) from Non-Road Mobile Machinery (NRMM). Liebherr Machines Bulle, Ecole Centrale Paris, Master Thesis.

Saidani, M., Yannou, B., Leroy, Y., Cluzel, F., 2017. How to Close the Loop of Platinum from Heavy Vehicles Catalytic Converters? Framework to Evaluate the Impact of Several Promising Action Levers. ISIE-ISSST Joint Conference, June 2017, Chicago, United States.

Saidani, M., Yannou, B., Leroy, Y., Cluzel, F., 2018. Heavy vehicles on the road towards the circular economy: Analysis and comparison with the automotive industry. Resources, Conservation and Recycling, 135, 108-122.

Saltelli, A., Ratto, M., Andres, T., Campolongo, F., Cariboni, J., Gatelli, D., et al., 2008. Global Sensitivity Analysis: The Primer. Wiley.

Saurat, M, Bringezu, S., 2008. Platinum Group Metal Flows of Europe, Part 1. J. Ind. Ecol. 12, 754-767.

Senk, D., Meyer, F., Pretz, T., Abrasheva, G., 2012. Strategies for fulfilment of critical raw materials demand in Europe. Revue De Métallurgie, 109 (5), 333-339.

Sievers, H., Tercero, L., 2012. European dependence on and concentration tendencies of the material production. Polinares, EU Policy on Natural Resources, March 2012.

Sinha, R., Laurenti, R., Singh, J., Frostell, B., 2014. System dynamics approach for investigating a circular economy in the global mobile phone product system. The international conferences ICT4S - ICT for Sustainability.

Stahel, W. R., 2016. The circular economy. Nature, 531, 435-438.

Statista, 2017. Vehicles road traffic. Accessed on April 2018: http://www.statista.com/markets/419/topic/487/vehiclesroad-traffic.

Takeyama, K., Ohno, H., Matsubae, K., Nakajima, K., Kondo, Y., Nagasaka, T., 2016. Dynamic material flow analysis of nickel and chromium associated with steel materials by using MaTrace. Matériaux \& Techniques, 104, 6-7, 610.

UNEP, 2013. Metal Recycling-Opportunities, Limits, Infrastructure - A Report of the Working Group on the Global Metal Flows to the International Resource Panel. United Nations Environment Program: Paris, France.

Valérian, F., 2016. Métaux rares et dépendance stratégique. Annales des Mines - Responsabilité et environnement, 2, 82. French.

Van der Voet, E., Van Oers, L., Verboon, M., Kuipers, K., 2018. Environmental Implications of Future Demand Scenarios for Metals: Methodology and Application to the Case of Seven Major Metals. Journal of Industrial Ecology. doi:10.1111/jiec.12722

Wang, Y., Li, X., 2012. Health Risk of Platinum Group Elements from Automobile Catalysts. Procedia Engineering, 45, 1004-1009.

Weidema B., Wesnaes M. S., 1996. Data quality management for life cycle inventories - an example of using data quality indicators. Journal of Cleaner Production, 4, 167-174.

Weiland, F. W., 2014. European remanufacturing of heavy-duty and off-road vehicle components (including tyres): a hidden giant? FWJ Consulting, May 2014 198.

Wernick, I. K., Ausubel, J. H., 1995. National material metrics for industrial ecology. Resources Policy, 21 (3), 189 -

Zio, E., 2013. The Monte Carlo Simulation Method for System Reliability and Risk Analysis. London: Springer (Springer Series in Reliability Engineering). 